\title{
A Reason-Based Approach to Coherence in Customary International Law
}

Citation for published version (APA):

Marcos, H. (2021). A Reason-Based Approach to Coherence in Customary International Law. Paper presented at 2nd TRICl-Law Conference, The Hague, Netherlands.

Document status and date:

Published: 03/12/2021

Document Version:

Early version submitted to journal

\section{Please check the document version of this publication:}

- A submitted manuscript is the version of the article upon submission and before peer-review. There can be important differences between the submitted version and the official published version of record.

People interested in the research are advised to contact the author for the final version of the publication, or visit the DOI to the publisher's website.

- The final author version and the galley proof are versions of the publication after peer review.

- The final published version features the final layout of the paper including the volume, issue and page numbers.

Link to publication

\footnotetext{
General rights rights.

- You may freely distribute the URL identifying the publication in the public portal. please follow below link for the End User Agreement:

www.umlib.nl/taverne-license

Take down policy

If you believe that this document breaches copyright please contact us at:

repository@maastrichtuniversity.nl

providing details and we will investigate your claim.
}

Copyright and moral rights for the publications made accessible in the public portal are retained by the authors and/or other copyright owners and it is a condition of accessing publications that users recognise and abide by the legal requirements associated with these

- Users may download and print one copy of any publication from the public portal for the purpose of private study or research.

- You may not further distribute the material or use it for any profit-making activity or commercial gain

If the publication is distributed under the terms of Article $25 \mathrm{fa}$ of the Dutch Copyright Act, indicated by the "Taverne" license above, 

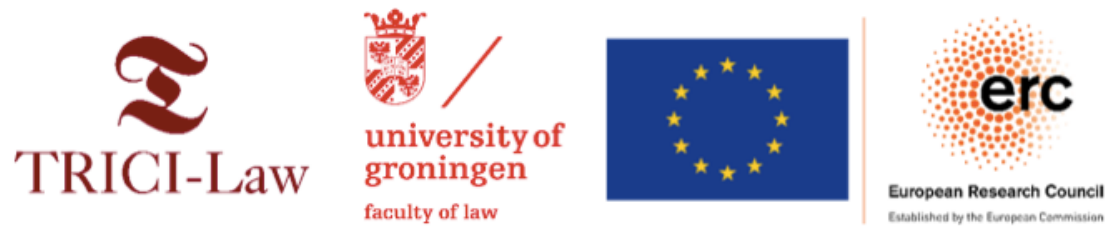

\title{
PLURI C撛URTS
}

Interpretation of Customary International Law:

Methods, Interpretative Choices and the Role of Coherence

$2^{\text {nd }}$ TRICI-Law Conference, $2^{\text {nd }}$ and $3^{\text {rd }}$ of December 2021, The Hague

\section{A Reason-Based Approach to Coherence in Customary International Law}

\author{
(5000-Word Paper)
}

Henrique $\operatorname{Marcos}^{1}$

\begin{abstract}
This paper focuses on customary international law (CIL) to point out some limitations of a deductive-syllogistic style of reasoning. It emphasises two CIL complexities. First, even well-established CIL rules are known to have exceptions, but that does not call for the conclusion that a CIL rule is non-existent. Second, the preceding practice for recognising a CIL rule does not need to be uniform. If one attempts to explain such complexities employing a syllogism-oriented, deductive style of reasoning, one will face severe difficulties and mismatches between the law and the model in place. While deductivism ties coherence to the absence of contradiction, legal reasoning allows coherence to find its way out of contradiction. As an alternative to the deductive model, this paper argues that reason-based logic (RBL) provides a suitable framework for understanding the law and CIL complexities. This logic is reason-based because it gives the centre stage to reasons instead of syllogisms, allowing one to balance reasons in favour and against a conclusion. This paper is structured as follows: Section 1 focuses on the two abovementioned CIL complexities. Section 2 examines deductivism and points out why it is unable to account for such complexities. Section 3 introduces the reasonbased alternative. Section 4 concludes the paper.
\end{abstract}

Keywords: Customary International Law. Legal Reasoning. Non-Deductive Reasoning. Reason-Based Logic.

\footnotetext{
${ }^{1} \mathrm{PhD}$ researcher in Law at Maastricht University and the University of São Paulo. Researcher at the Centre for Research in International Courts (Núcleo de Estudos em Tribunais Internacionais, NETI) at the University of São Paulo and Globalization and Law Network (GLaw-Net) at Maastricht University. E-mail: henriquejbmarcos@gmail.com. (The CAPES Foundation, Brazil, partially financed this study.)

The author thanks Antonia Waltermann, Jaap Hage, and Wagner Menezes for reading and commenting initial versions of this paper. In any case, all errors are the author's responsibility.
} 


\section{Introduction}

Coherence is a popular topic. A lot can be said about coherence and coherentism in epistemology, ethics, and law. In the international legal sphere, coherence took centre stage due to the ongoing debate on international law's unity and fragmentation. ${ }^{2}$ But it is not clear if every legal scholar is speaking of the same thing when using this term. Some speak of coherence as rule consistency (in the sense of the lack of rule conflicts). ${ }^{3}$ Occasionally, lawyers talk of coherence (or lack thereof), connecting it to the uniform (or disorderly) application of international law and the (un)predictable activity of coexisting international courts and organisations. ${ }^{4}$ Coherence and coherentism can too be connected to theories on justification as an alternative to foundationalism. ${ }^{5}$ In this paper, coherence is tied to the possibility of intelligible argument within law.

In that connection, there is a long tradition in jurisprudence that insists that the law's coherence is dependent on a formal, constitutive structure. As Postema mentions, ${ }^{6}$ there have been many iterations of this tradition: Hobbes and Austin consigned that structural role to the sovereign $;{ }^{7}$ Hart chose the rule of recognition; ${ }^{8}$ Kelsen found it in the Grundnorm. ${ }^{9}$ In one way or another, this tradition has inspired several theoretical standpoints. ${ }^{10}$ One of which is the belief that legal reasoning functions similarly to a deductive syllogism, where a conclusion is drawn by applying general rules to a closed domain. This paper will call this view "deductivism." It is

\footnotetext{
2 Radi Yannick, 'Coherence' in Jean D'Aspremont and Sahib Singh (eds), Concepts for international law: contributions to disciplinary thought (Edward Elgar Publishing 2019); Mads Andenas and others (eds), General Principles and the Coherence of International Law (Brill Nijhoff 2019)

${ }^{3}$ Haack has addressed the differences between coherence and other "co-" terms such as consistency and cohesiveness. See: Susan Haack, 'Coherence, Consistency, Cogency, Congruity, Cohesiveness, \&c.: Remain Calm! Don’t Go Overboard!' (2004) 35 New Literary History 167

${ }^{4}$ Wagner Menezes, Tribunais Internacionais: Jurisdição e Competência (Saraiva 2013). See also: Henrique Marcos, Antonia Waltermann and Jaap Hage, 'From Sovereignty to International Cooperation: Lessons from Legal Logic and Social Ontology', National Sovereignty and International Co-operation: The Challenges of Navigating Global Crises (Cambridge Journal of International Law 2021).

${ }^{5}$ Amalia Amaya, 'Coherence and Systematization in Law' in Giorgio Bongiovanni and others (eds), Handbook of Legal Reasoning and Argumentation (Springer Netherlands 2018) <http://link.springer.com/10.1007/978-90-4819452-0_22> accessed 5 October 2020; Jaap Hage, 'Law and Coherence', Studies in Legal Logic (Springer 2005); Jaap Hage, 'Three Kinds of Coherentism' in Michał Araszkiewicz and Jaromír Šavelka (eds), Coherence: Insights from Philosophy, Jurisprudence and Artificial Intelligence (Springer 2013).

6 "A long tradition in philosophical jurisprudence - going back at least to Hobbes - insists that the unity and coherence of law, and the possibility of intelligible argument within law, depend on some formal, constitutive structure. For Hobbes and Austin, this was the sovereign and its commands; for Hart this is a complex 'rule of recognition'; for Kelsen it was the Grundnorm." Gerald J Postema, "Protestant" Interpretation and Social Practices' (1987) 6 Law and Philosophy 283, 317-318

7 Thomas Hobbes, Leviathan (Christopher Brooke ed, Penguin Books 2017); John Austin, The Province of Jurisprudence Determined (Wilfrid E Rumble ed, 1st edn, Cambridge University Press 1995)

${ }^{8}$ HLA Hart, The Concept of Law (3rd edn, Oxford University Press 2012).

${ }^{9}$ Hans Kelsen, Pure Theory of Law (Max Knight tr, University of California Press 1967).

${ }^{10}$ That is not to say that exponents of this tradition would agree with all derivative theoretical standpoints.
} 
an attractive view in some ways, but it is also plagued with some limitations that prevent it from adequately modelling legal reasoning.

This paper focuses on customary international law (CIL) to point out some of these limitations. CIL is a concept concerning both the formative process for the existence of certain kinds of international legal rules as well as such rules. ${ }^{11}$ Narrowing its scope, the investigation is centred on two complexities concerning CIL. First, even well-established CIL rules are known to have exceptions, but that does not call for the conclusion that a CIL rule is no longer existent. ${ }^{12}$ Second, the preceding practice for recognising a CIL rule does not need to be uniform - international law is lenient to some contradiction (such as the non-conforming practice of States) as long as non-contradictory input (conforming practice) is sufficient.

If one attempts to explain such complexities employing a syllogism-oriented, deductive style of reasoning, one will face severe difficulties and mismatches between the law and the model in place. While deductivism ties coherence to absence of contradiction (premises cannot be true and the conclusion false), legal reasoning allows coherence to find its way out of contradiction. As an alternative to the deductive model, this paper argues that reason-based logic (RBL) provides a suitable framework for understanding the law and CIL complexities. This logic is reason-based because it gives the centre stage to reasons instead of syllogisms, allowing one to balance reasons in favour and against a conclusion.

This investigation aims to contribute to the growing discussion on legal reasoning and argumentation theory in international law. ${ }^{13} \mathrm{~A}$ debate that seems particularly relevant in light of recent criticism directed against international courts. Talmon, for instance, offers a rich study of some methodological choices made by judges who claim to employ "deductive methods" to determine CIL. ${ }^{14}$ Despite Talmon's efforts on differentiating the "logic of syllogism" from the

\footnotetext{
${ }^{11}$ To avoid confusion, this paper refers to the formative process as "CIL process" or "process" and the rules that flow from this process as "CIL rules" or "rules." See Tulio Treves, 'Customary International Law' in Rüdiger Wolfrum (ed), Max Planck Encyclopedia of Public International Law (Oxford University Press 2006).

12 This paper talks of valid rules as existing rules to avoid confusion with logical validity as the property of an argument.

${ }^{13}$ Martti Koskenniemi, 'Methodology of International Law' in Rüdiger Wolfrum (ed), Max Planck Encyclopedia of Public International Law (2007); Ingo Venzke, 'International Law as an Argumentative Practice: On Wohlrapp's "The Concept of Argument" (2016) 7 Transnational Legal Theory 9 $<$ https://www.tandfonline.com/doi/full/10.1080/20414005.2016.1192357> accessed 27 March 2021; Ingo Venzke, 'What Makes for a Valid Legal Argument?' (2014) 27 Leiden Journal of International Law 811 $<$ https:/www.cambridge.org/core/product/identifier/S0922156514000363/type/journal_article> accessed 27 March 2021; Jean D’Aspremont, Epistemic Forces in International Law (Edward Elgar Publishing 2015) $<$ http://www.elgaronline.com/view/9781781955277.xml> accessed 27 March 2021.

${ }^{14}$ Stefan Talmon, 'Determining Customary International Law: The ICJ's Methodology between Induction, Deduction and Assertion' (2015) 26 European Journal of International Law 417 $<$ https://academic.oup.com/ejil/article-lookup/doi/10.1093/ejil/chv020> accessed 22 August 2021.
} 
"logic of law," this paper understands that more analytic clarity is still needed to demonstrate that deductive logic is not suited to model legal reasoning. ${ }^{15}$

The paper is structured as follows. Section 1 focuses on the two abovementioned CIL complexities. Section 2 examines deductivism and points out why it is unable to account for such complexities. Section 3 introduces the reason-based alternative. Section 4 concludes the paper.

\section{CIL Complexities}

All CIL rules share the way that they come into existence. They emerge from certain facts that possess two dimensions: first, the general repetition of a specific practice by States and, second, an underlying belief that such practice is carried out as a legal obligation (opinio juris sive necessitatis). For now, the interesting bit is the "general" aspect of the first dimension.

The general practice that gives rise to a CIL rule does not need to be entirely uniform. As the International Court of Justice (ICJ) has decided in the North Sea Continental Shelf Case, ${ }^{16}$ it is sufficient that the practice is extensive and virtually uniform, especially with those States significantly affected by it. Contrario sensu, one can conclude that for the CIL rule to arise, some States can still engage in non-conforming practice. There can be considerable contradiction as long as conforming practice is sufficient to justify recognising a CIL rule.

Similarly, in the Nicaragua Case ${ }^{17}$ the ICJ stated that the emergence of a CIL rule does not require absolutely rigorous conformity with such a rule. General conformity is acceptable if contradictory behaviour is seen as a breach or an exception to the rule. In that regard, the ICJ stated that such violations and exceptions serve as confirmation of their existence as rules. There would be no need to make an exception and nothing to breach if these CIL rules were non-existent. ${ }^{18}$

Notice the two CIL complexities at play. First, exceptions can be made to a CIL rule, but these exceptions do not undermine the rule's existence. ${ }^{19}$ Second, a successful CIL process

\footnotetext{
${ }^{15}$ Due to the limitations of space, this paper will ignore some issues with Talmon's attempt to differentiate "logical deductive reasoning" from "legal deductive reasoning."

${ }^{16}$ North Sea Continental Shelf, Judgment [1969] ICJ Reports 3 (International Court of Justice, ICJ), paragraphs 73-74.

${ }^{17}$ Military and Paramilitary Activities in and against Nicaragua (Nicaragua v United States of America), Merits, Judgment [1986] ICJ Reports 14 (International Court of Justice, ICJ), paragraph 186.

18 "If a State acts in a way prima facie incompatible with a recognised rule, but defends its conduct by appealing to exceptions or justifications contained within the rule itself, then whether or not the State's conduct is in fact justifiable on that basis, the significance of that attitude is to confirm rather than to weaken the rule." ibid.

${ }_{19}$ This paper chooses to ignore breaches of CIL rules because it is an unlawful practice.
} 
allows for contradictory input (non-conforming practice) if such input does not outweigh alternative input leading to the rule's emergence.

\section{Deductivism and its Limitations}

Deductivism is a widespread belief that legal reasoning functions similarly to deductive syllogism, where a conclusion is drawn by applying general rules to a closed domain. In deductivism, the rules supplying the structure precede the practices that apply it to a case. ${ }^{20}$ As such, it is expected that a rule will play the role of the major premise. The minor premise consists of a description of the facts of a case that one is dealing with. Joining these two, one would be able to deduce the conclusion - the legal consequence of that case.

It is important to emphasise that, despite some overlap, legal deductivism is not necessarily identical to a view that Leiter calls "vulgar formalism," which assumes that decision-making is nothing more than "a mechanical deduction on the model of the [deductive] syllogism. ${ }^{" 21}$ Legal deductivism seems more sophisticated, for it is not tied to decision-making per se but to the reasoning behind a decision (a legal conclusion) and its justification. A view, it seems, that Leiter himself subscribes: "deductive reasoning on the model of syllogism is a characteristic feature of most well-done judicial opinions [...]." ${ }^{22} \mathrm{MacCormick}^{23}$ and Marmor ${ }^{24}$ seem to advocate for an analogous view. ${ }^{25}$

\footnotetext{
20 "[...] it is 'deductive' in the sense that the rules that structure it are posited prior to the practices that apply it." Pierre Legrand, 'Against a European Civil Code' (1997) 60 Modern Law Review 44, 48 $<$ https://onlinelibrary.wiley.com/doi/10.1111/1468-2230.00065> accessed 21 August 2021. See also Jaap Hage, 'Legal Reasoning and Legal Integration', Studies in Legal Logic (Springer 2005).

${ }^{21}$ Brian Leiter, 'Legal Formalism and Legal Realism: What Is the Issue?' (2010) 16 Legal Theory 111. See also: Luis Duarte d'Almeida, 'On the Legal Syllogism' in D Plunkett, SJ Shapiro and K Toh (eds), Dimensions of Normativity: New Essays on Metaethics and Jurisprudence (Oxford University Press 2019).

22 Leiter (n 21).

23 " [...] the legal reasoning advanced to justify legal claims or legal decisions can sometimes be entirely, and must always be in part, deductive in its essence. The thesis was that legal rules are properly conceptualised as hypothetical in form, prescribing that if certain circumstances (certain 'operative facts') obtain, then certain normative consequences are to follow." Neil MacCormick, 'Legal Deduction, Legal Predicates and Expert Systems' (1992) 5 International Journal for the Semiotics of Law 181,182 $<$ http://link.springer.com/10.1007/BF01101868> accessed 21 August 2021.

24 "It is, after all, the regular business of lawyers and judges to draw legal inferences. Many of those inferences look like an ordinary syllogism, whereby a conclusion is derived from some premises about the normative content of the law and statements describing facts or events." Andrei Marmor, The Language of Law (First edition, Oxford University Press 2014) 61.

${ }^{25}$ For an analysis of deductivism in legal reasoning, see Duarte d'Almeida (n 21).

It is relevant to emphasise that a charitable reading of deductivism must notice the difference between a legal conclusion's internal and external justification. Wróblewski differentiates them by explaining that internal justification is a matter of deriving a conclusion according to the accepted rules of valid inference. It is linked to "internal rationality," as Aarnio explains. External justification, in turn, is connected to whether the premises are
} 
One must admit that deductive reasoning is attractive. If all premises are true and the rules of deductive logic are followed, then the conclusion is necessarily true, leaving no room for uncertainty. ${ }^{26}$ Nevertheless, adopting deductivism can also lead to some complications. Deductivism leaves no room for contradictory input nor allows balancing before reaching a conclusion. These two aspects are particularly relevant because CIL is tolerant to some deviations between conditions (as premises) and the possible conclusions that they lead.

For instance, take exceptions to CIL rules. In an exception, a CIL rule is applicable to a case, but it is nevertheless not applied. That is not possible under a deductivist model. If the CIL rule matches the case's fact situation, the conclusion should be that the applicable CIL rule must be applied to the case. A decision that concludes otherwise cannot be had unless one assumes that the CIL rule (acting as a major premise) is non-existent. ${ }^{27}$ The problem is that, as mentioned in section 2, such exceptions do take place in practice, and they do not warrant the rule's non-existence. As the ICJ concluded, exceptions serve to confirm a CIL rule's existence (if the rule were non-existent, there would be nothing to make an exception to). Likewise, deductivism leaves no clear space for balancing conforming and non-conforming practices (contradictory input) to recognise whether a CIL rule exists. ${ }^{28}$

\section{Reason-Based Logic}

The section above shows that there seems to be certain lenience in (customary) international law that is not found in deductive reasoning. Shortly put, in valid deductive

"good" according to the standards used by who makes the qualification, i.e., whether the inference is sound. Deductivists are concerned with internal justification. See Jerzy Wroblewski, 'Legal Syllogism and Rationality of Judicial Decision Abhandlungen Und Aufsatze' (1974) 5 Rechtstheorie 33 , 39 $<\mathrm{https}$ //heinonline.org/HOL/P?h=hein.journals/recthori5\&i=39> accessed 21 August 2021. Aulis Aarnio, Rational as Reasonable: A Treatise on Legal Justification (Springer Netherlands 1986) 119.

The justification of a legal conclusion, according to deductivism, is always a matter of deduction. Following MacCormick, justification can be entirely or partially deductive, but it must always be in part deductive in its essence. See MacCormick (n 23) 182.

${ }^{26}$ Given the limitations of space, this paper ignores the complication of reasoning with premises lacking a truth value. Nonetheless, it is interesting to point out that Marmor, for one, recognises such a complication: "It is difficult to see how such inferences can be valid if the premises are not truth-apt, that is, if legal prescriptions have no truthevaluable content." Marmor (n 24) 61.

${ }^{27}$ In other words, if the CIL rule applies to the case and the CIL rule exists, then, under a deductivist model, the conclusion is that the CIL rule's legal consequences are to be attached to the case.

${ }^{28}$ One might attempt to defend deductive reasoning by arguing that there may be "hidden rule-conditions," which are not exceptions. Due to the restriction of space, it will not be possible to counter-argue such claims here.

For the interested reader, see Jaap Hage and Bart Verheij, 'Reason-based Logic: A Logic for Reasoning with Rules and Reasons' (1994) 3 Information \& Communications Technology Law 171, 173; Jaap Hage, Antonia Waltermann and Gustavo Arosemena Solorzano, 'Exceptions in International Law' in Lorand Bartels and Federica Paddeu (eds), Exceptions and Defences in International Law (Oxford University Press 2018). 
reasoning, the premises cannot be true and the conclusion false. Meanwhile, in CIL, there is flexibility between conditions and conclusions.

One could still insist on deductivism, trying to force CIL into the rigid mould offered by this kind of reasoning. But it is also possible to look for an alternative. This might seem surprising to those who carry the misconception that "reasoning is deducing," but deductive reasoning is just one mode of reasoning. ${ }^{29}$ Non-deductive reasoning, such as defeasible reasoning, is also a possibility.

It is crucial to notice that there is no such thing as the logic. There are many viable logics, and none is a priori better than the others. Consequently, deciding which one should be used is a matter of strategic choice. The logic that is the "best" for a particular task depends on the purpose that it is going to serve. In any case, in the choice of logic for a specific domain, one should strive for a conceptual framework that is as close as possible to the domain under analysis - logics that fail in this respect are not helpful for testing the arguments that agents can adduce in that domain. ${ }^{30}$

As such, a logic that allows for defeasible reasoning may help model legal reasoning. Defeasibility is tied to processes that respond to standard inputs with a certain kind of result (default outcomes) but may deliver different results when such inputs are supplemented with further elements. ${ }^{31}$

For example, one can think of the general rule prohibiting the use of force between States laid down in conventional and customary sources of international law. ${ }^{32}$ Suppose that State $\mathrm{X}$ has used force against State Y, and the case is brought before a Court. If Y is successful in

29 John L Pollock, 'Defeasible Reasoning' (1987) $11 \quad$ Cognitive Science 481 $<$ http://doi.wiley.com/10.1207/s15516709cog1104_4> accessed 9 July 2021; Susan Haack, Philosophy of Logics (16th printing, Cambridge Univ Press 2007).

${ }^{30}$ Jaap Hage, 'What to Expect from Legal Logic?' in Bart Verheij and others (eds), Legal Knowledge and Information Systems (IOS Press 2001).

${ }^{31}$ Pollock (n 29); Robert Koons, 'Defeasible Reasoning' in Edward N Zalta (ed), The Stanford Encyclopedia of Philosophy (Winter 2017, Metaphysics Research Lab, Stanford University 2017) $<$ https://plato.stanford.edu/archives/win2017/entries/reasoning-defeasible/> accessed 9 February 2021.

Connecting defeasible reasoning to the law in general, see: Jaap Hage, 'Law and Defeasibility', Studies in Legal Logic (Springer 2005); Giovanni Sartor, 'Defeasibility in Law' in Giorgio Bongiovanni and others (eds), Handbook of Legal Reasoning and Argumentation (Springer Netherlands 2018) $<\mathrm{http}$ //link.springer.com/10.1007/978-90-481-9452-0> accessed 5 October 2020.

Connecting defeasibility to international law, see: Henrique Marcos, 'A Study on Defeasibility and Defeaters in International Law: Process or Procedure Distinction Against the Non-Discrimination Rule’, Forthcoming (2021); Hage, Waltermann and Arosemena Solorzano (n 28).

${ }^{32}$ See Oliver Dörr, 'Use of Force, Prohibition Of' in Rüdiger Wolfrum (ed), Max Planck Encyclopedia of Public International Law (Oxford University Press 2019). See also: Military and Paramilitary Activities in and against Nicaragua (Nicaragua v. United States of America), Merits, Judgment (n 17), paragraphs 187 f. Legal Consequences of the Construction of a Wall in the Occupied Palestinian Territory, Advisory Opinion [2004] ICJ Reports 136 (International Court of Justice, ICJ) paragraph 87. 
proving that $\mathrm{X}$ has used force against $\mathrm{Y}$, the Court will be justified to conclude that $\mathrm{X}$ has acted unlawfully, thereby allowing the Court to attach the proper legal consequences to the fact that $\mathrm{X}$ has committed an act prohibited by international law. ${ }^{33}$ However, if $\mathrm{X}$ is able to defend itself by proving that it used force against $Y$ by exercising its right of self-defence, acceptance of X's claim by the Court may take the justification away from ruling that X's actions were unlawful. This means that the information that $\mathrm{X}$ has acted under self-defence may function as a justification defeater for the earlier conclusion that $\mathrm{X}$ has incurred in unlawful action against $\mathrm{Y}$.

Defeasible reasoning provides the initial outline for developing an alternative viewpoint on coherence in legal reasoning. It helps understand how there can be exceptions and contradictions between premises and conclusions without incoherence in law. This is possible because defeasibility reshapes the bond between premises and conclusions by making it more flexible. There is still a link between them, but now such a relationship is one of tentative support that can be defeated by additional input.

This paper will use a special kind of logic for defeasible reasoning, reason-based logic (RBL). ${ }^{34}$ This logic is notably different from deductivism because RBL gives the crucial role to reasons instead of syllogisms, allowing it to account for reasons for and against a particular conclusion. A reason is a fact that pleads for (pro) or against (con) a particular conclusion. For example, the fact that Mary looks like Lucy is a pro reason for concluding that they are related. Conversely, the fact that a DNA test pointed out that Mary and Lucy have different genetic makeup is a con reason for that conclusion.

By universalising a reason, one obtains a general connection between kinds of facts. A legal rule can make this connection. ${ }^{35}$ An example of such universalisation in international law is the connection between the use of force between States and the unlawful nature of such action via the rule mentioned above prohibiting these acts.

In practice, there are often cases where one is faced with multiple reasons, some of them pleading for and some against a particular conclusion. In such situations, it is necessary to balance these reasons. The outcome of this operation is a decision on which kinds of reasons (pro or con) outweigh the opposing set. Notice, therefore, that the presence of a reason for or

\footnotetext{
${ }^{33}$ For the purposes herein, the paper will consider that one has acted unlawfully when one has committed a prohibited act and vice-versa.

${ }^{34}$ RBL has been developed mainly by Hage. See Hage and Verheij (n 28); Jaap Hage, Reasoning with Rules: An Essay on Legal Reasoning and Its Underlying Logic (Springer Science + Business 1997); Jaap Hage, 'ReasonBased Logic', Studies in Legal Logic (Springer 2005).

${ }^{35}$ Jaap Hage, 'The Justification of Value Judgments: Theoretical Foundations for Arguments about the Best Level to Regulate European Private Law' in Bram Akkermans and others (eds), Who does what? on the allocation of regulatory competences in European private law (Intersentia; Metro 2015).
} 
against a conclusion does not determine the conclusion. Only the balance of all (pro and con) reasons leads to the decision on whether that conclusion obtains. ${ }^{36}$

This framework is particularly interesting to legal reasoning because it points to a rift between a rule's applicability and its application. In general, a rule is applicable to a case if that rule exists and that case matches the rule's conditions. The fact that a rule is applicable to a case is a reason to apply that rule. However, that reason can be outweighed by reasons against applying that applicable rule to that case. When that happens, an applicable rule is not applied - an exception was made. There are many reasons for making an exception. Two popular reasons are that applying the applicable rule to a case would violate that rule's purpose and situations where applying an applicable rule would lead to a rule conflict with another applicable rule.

What is interesting now is how this framework matches the exceptions that can be made to a CIL rule. The fact that a CIL rule is applicable is a pro reason to apply it. But that pro reason needs to be balanced against con reasons for applying that CIL rule. If the con reasons outweigh the pro reasons, the conclusion is an exception to the CIL rule. That is what happens in the hypothetical case between States X and Y. The Court is faced with a pro reason for the conclusion that $X$ 's usage of force is unlawful given the general rule prohibiting the use of force. At the same time, there is a con reason for such a conclusion since $\mathrm{X}$ was acting in self-defence. Balancing the reasons, the Court may decide against the unlawfulness of X's actions by judging that the con reasons outweigh the pro reasons for that conclusion. As such, the first CIL complexity is explained by RBL.

The second complexity concerning how CIL processes allow for contradictory and noncontradictory input is not so different. Here too, when reasoning about the existence of a CIL rule, one deals with the pro and con reasons at play. Among others, the pro reasons are the conforming practice of States that give rise to a new CIL rule, while the con reasons are nonconforming practices. In balancing such pro and con reasons, the outcome of the reasoning will recognise that a CIL rule exists when pro reasons outweigh con reasons. In turn, the conclusion will be that the CIL rule does not exist when con reasons outweigh pro reasons.

Alternatively, this second complexity can be sketched as the reasoning behind applying or not applying a rule. There is a meta-rule (a rule about rules) in international law positing that if specific facts obtain (namely, repeated practice by States and the belief that such practice is

\footnotetext{
${ }^{36}$ Given the limitations of space, this paper ignores the difference between contributory and decisive reasons. Thus, it treats all reasons as contributory.
} 
carried as a legal obligation), a particular legal consequence follows (that a specific CIL rule exists). ${ }^{37}$ In a case where that meta-rule's conditions are met, that meta-rule is applicable. If applied, that meta-rule recognises the existence of a CIL rule (that recognition has retroactive effects to when the conforming practice began). But an exception can be made to that metarule. If non-conforming practice is far too extensive, outweighing conforming practice, that serves as a reason for making an exception to the meta-rule. In case con reasons outweigh the pro reasons for applying the meta-rule, leading it not to be applied, the meta-rule will not attach its legal consequence (that a CIL rule exists) to the case.

The difference between these two alternatives for explaining the second complexity depends on whether a CIL rule is indeed a social rule or, instead, a rule-based rule. ${ }^{38}$ A social rule is a rule that exists if sufficiently many members of a group recognise the rule consequence if they believe the facts of the rule's conditions. Rule-based rules exist where (meta-)rules specify how new rules come about - rule-based rules result from rule-creation. In any case, the existence of a CIL rule is a constructivist fact. Constructivist facts are facts determined by reasons. They are social facts, meaning they are (or ought to be) recognised as social facts. But they are social facts resulting from the outcome of a reason-based reconstruction of the set of social facts recognised by a social group.

\section{Final Remarks}

This paper considered two complexities of CIL: exceptions to CIL rules and the fact that CIL processes allow for CIL rules to emerge despite contradictory input. These complexities were used to point out some limitations of the view that legal reasoning is deductive while identifying how a reason-based logic can adequately explain them.

Deductivism is an attractive view because it provides a straightforward explanation of how legal reasoning could work in certain instances. Under a deductivist light, however, coherence in the law requires an absolute lack of contradictory input. The problem is that legal practice is a space of constant contradiction. Adopting a non-deductivist logic can help understand how one can reach coherence despite such contradictory input. Reasoning is not the

\footnotetext{
${ }^{37}$ See the Statute of the International Court of Justice Article 38(1)(b).

${ }^{38}$ Jaap Hage, 'Constructivist Facts as the Bridge Between Is and Ought', Global Semiotics, Intercultural Legal Space and the Interplay between 'Facticity' and 'Normativity' (2021). Jaap Hage, Foundations and Building Blocks of Law (Eleven International Publishing 2018).
} 
process of ignoring contradiction, it is centred on figuring out how one can draw coherent conclusions out of them.

\section{References}

Aarnio A, Rational as Reasonable: A Treatise on Legal Justification (Springer Netherlands 1986)

Amaya A, 'Coherence and Systematization in Law' in Giorgio Bongiovanni and others (eds), Handbook of Legal Reasoning and Argumentation (Springer Netherlands 2018) < http://link.springer.com/10.1007/978-90-481-9452$0 \_22>$ accessed 5 October 2020

Andenas M and others (eds), General Principles and the Coherence of International Law (Brill Nijhoff 2019) $<$ https://brill.com/view/title/54087> accessed 6 January 2021

Austin J, The Province of Jurisprudence Determined (Wilfrid E Rumble ed, 1st edn, Cambridge University Press $1995)<$ https://www.cambridge.org/core/product/identifier/9780511521546/type/book> accessed 7 July 2021

D’Aspremont J, Epistemic Forces in International Law (Edward Elgar Publishing 2015)

$<$ http://www.elgaronline.com/view/9781781955277.xml> accessed 27 March 2021

Dörr O, 'Use of Force, Prohibition Of' in Rüdiger Wolfrum (ed), Max Planck Encyclopedia of Public International Law (Oxford University Press 2019)

Duarte d'Almeida L, 'On the Legal Syllogism' in D Plunkett, SJ Shapiro and K Toh (eds), Dimensions of Normativity: New Essays on Metaethics and Jurisprudence (Oxford University Press 2019)

Haack S, 'Coherence, Consistency, Cogency, Congruity, Cohesiveness, \&c.: Remain Calm! Don’t Go Overboard!' (2004) 35 New Literary History $167<$ https://www.jstor.org/stable/20057831> accessed 15 March 2021

—., Philosophy of Logics (16th printing, Cambridge Univ Press 2007)

Hage J, Reasoning with Rules: An Essay on Legal Reasoning and Its Underlying Logic (Springer Science + Business 1997)

—, 'What to Expect from Legal Logic?' in Bart Verheij and others (eds), Legal Knowledge and Information Systems (IOS Press 2001)

__, 'Law and Coherence', Studies in Legal Logic (Springer 2005)

—_, 'Law and Defeasibility', Studies in Legal Logic (Springer 2005)

—_ 'Legal Reasoning and Legal Integration', Studies in Legal Logic (Springer 2005)

—_, 'Reason-Based Logic', Studies in Legal Logic (Springer 2005)

— 'Three Kinds of Coherentism' in Michał Araszkiewicz and Jaromír Šavelka (eds), Coherence: Insights from Philosophy, Jurisprudence and Artificial Intelligence (Springer 2013)

— 'The Justification of Value Judgments: Theoretical Foundations for Arguments about the Best Level to Regulate European Private Law' in Bram Akkermans and others (eds), Who does what? on the allocation of regulatory competences in European private law (Intersentia; Metro 2015) 
__, Foundations and Building Blocks of Law (Eleven International Publishing 2018)

— 'Constructivist Facts as the Bridge Between Is and Ought', Global Semiotics, Intercultural Legal Space and the Interplay between 'Facticity' and 'Normativity' (2021)

Hage J and Verheij B, 'Reason-based Logic: A Logic for Reasoning with Rules and Reasons' (1994) 3 Information \& Communications Technology Law 171

$<$ http://www.tandfonline.com/doi/abs/10.1080/13600834.1994.9965701> accessed 19 June 2021

Hage J, Waltermann A and Arosemena Solorzano G, 'Exceptions in International Law' in Lorand Bartels and Federica Paddeu (eds), Exceptions and Defences in International Law (Oxford University Press 2018)

Hart HLA, The Concept of Law (3rd edn, Oxford University Press 2012)

Hobbes T, Leviathan (Christopher Brooke ed, Penguin Books 2017)

Kelsen H, Pure Theory of Law (Max Knight tr, University of California Press 1967)

Koons R, 'Defeasible Reasoning' in Edward N Zalta (ed), The Stanford Encyclopedia of Philosophy (Winter 2017, Metaphysics Research Lab, Stanford University 2017)

$<$ https://plato.stanford.edu/archives/win2017/entries/reasoning-defeasible/> accessed 9 February 2021

Koskenniemi M, 'Methodology of International Law' in Rüdiger Wolfrum (ed), Max Planck Encyclopedia of Public International Law (2007)

Legrand P, ‘Against a European Civil Code’ (1997) 60 Modern Law Review 44 $<$ https://onlinelibrary.wiley.com/doi/10.1111/1468-2230.00065> accessed 21 August 2021

Leiter B, 'Legal Formalism and Legal Realism: What Is the Issue?' (2010) 16 Legal Theory 111

MacCormick N, 'Legal Deduction, Legal Predicates and Expert Systems' (1992) 5 International Journal for the Semiotics of Law $181<$ http://link.springer.com/10.1007/BF01101868> accessed 21 August 2021

Marcos H, 'A Study on Defeasibility and Defeaters in International Law: Process or Procedure Distinction Against the Non-Discrimination Rule', Forthcoming (2021)

Marcos H, Waltermann A and Hage J, 'From Sovereignty to International Cooperation: Lessons from Legal Logic and Social Ontology’, National Sovereignty and International Co-operation: The Challenges of Navigating Global Crises (Cambridge Journal of International Law 2021)

Marmor A, The Language of Law (First edition, Oxford University Press 2014)

Menezes W, Tribunais Internacionais: Jurisdição e Competência (Saraiva 2013)

Pollock JL, 'Defeasible Reasoning' (1987) 11 Cognitive Science 481

$<$ http://doi.wiley.com/10.1207/s15516709cog1104_4> accessed 9 July 2021

Postema GJ, “"Protestant” Interpretation and Social Practices' (1987) 6 Law and Philosophy 283

Sartor G, 'Defeasibility in Law' in Giorgio Bongiovanni and others (eds), Handbook of Legal Reasoning and Argumentation (Springer Netherlands 2018) <http://link.springer.com/10.1007/978-90-481-9452-0> accessed 5 October 2020 
Talmon S, 'Determining Customary International Law: The ICJ's Methodology between Induction, Deduction and Assertion' (2015) 26 European Journal of International Law $417<$ https://academic.oup.com/ejil/articlelookup/doi/10.1093/ejil/chv020> accessed 22 August 2021

Treves T, 'Customary International Law' in Rüdiger Wolfrum (ed), Max Planck Encyclopedia of Public International Law (Oxford University Press 2006)

Venzke I, ‘What Makes for a Valid Legal Argument?' (2014) 27 Leiden Journal of International Law 811 $<$ https://www.cambridge.org/core/product/identifier/S0922156514000363/type/journal_article> accessed 27 March 2021

_- 'International Law as an Argumentative Practice: On Wohlrapp's "The Concept of Argument"' (2016) 7 Transnational Legal Theory $9<$ https://www.tandfonline.com/doi/full/10.1080/20414005.2016.1192357> accessed 27 March 2021

Wroblewski J, 'Legal Syllogism and Rationality of Judicial Decision Abhandlungen Und Aufsatze' (1974) 5 Rechtstheorie $33<\mathrm{https}$ :/heinonline.org/HOL/P?h=hein.journals/recthori5\&i=39> accessed 21 August 2021

Yannick R, 'Coherence' in Jean D'Aspremont and Sahib Singh (eds), Concepts for international law: contributions to disciplinary thought (Edward Elgar Publishing 2019)

Legal Consequences of the Construction of a Wall in the Occupied Palestinian Territory, Advisory Opinion [2004] ICJ Reports 136 (International Court of Justice, ICJ)

Military and Paramilitary Activities in and against Nicaragua (Nicaragua v United States of America), Merits, Judgment [1986] ICJ Reports 14 (International Court of Justice, ICJ)

North Sea Continental Shelf, Judgment [1969] ICJ Reports 3 (International Court of Justice, ICJ) 